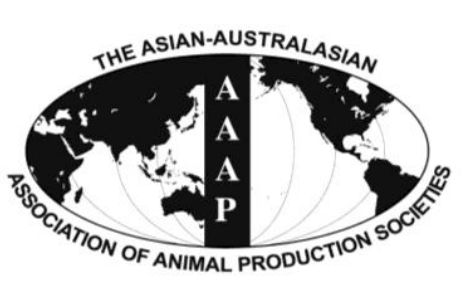

\begin{tabular}{c} 
Open Access \\
Asian Australas. J. Anim. Sci. \\
Vol. 27, No. 4 : 503-510 April 2014 \\
http://dx.doi.org/10.5713/ajas.2013.13533 \\
\hline www.ajas.info \\
pISSN 101 1-2367 elSSN 1976-5517
\end{tabular}

\title{
Growth Performance, Carcass Characteristics and Meat Yield of Boer Goats Fed Diets Containing Leaves or Whole Parts of Andrographis paniculata
}

\author{
A. L. Yusuf ${ }^{1,5}$, Y. M. Goh ${ }^{2,3}$, A. A. Samsudin ${ }^{1}$, A. R. Alimon ${ }^{1}$, and A. Q. Sazili ${ }^{1,4, *}$ \\ ${ }^{1}$ Department of Animal Science, Faculty of Agriculture, Universiti Putra Malaysia, \\ 43400 UPM Serdang, Selangor D.E., Malaysia
}

\begin{abstract}
The study was conducted to determine the effect of feeding diets containing Andrographis paniculata leaves (APL), whole Andrographis paniculata plant (APWP) and a control without Andrographis paniculata (AP0), on growth performance, carcass characteristics and meat yield of 24 intact Boer bucks. The results obtained indicated that inclusion of Andrographis paniculata significantly improved feed intake, weight gain, feed efficiency and live weight. The ratios of carcass to fat, lean to bone, lean to fat, and composition of meat were also improved. In addition, there were significant differences $(\mathrm{p}<0.05)$ between the dietary treatments in dressing percentage and chilling loss. Goats fed on AP0 (control) had significantly higher proportions of fat and bone, as well as thicker back fat than the supplemented animals (APL and APWP). Higher gut fill in animals fed Andrographis paniculata suggested slow rate of digestion, which could have improved utilization and absorption of nutrients by the animals. Goats fed Andrographis paniculata also produced higher meat yield and relatively lower fat contents $(\mathrm{p}<0.05)$. (Key Words: Andrographis paniculata, Goats, Growth, Carcass, Meat)
\end{abstract}

\section{INTRODUCTION}

Feeding sub-therapeutic levels of antibiotics to livestock has been in practice for a very long period. Antibiotics play vital role in improving health, feed efficiency and overall animal performance. The ability of antibiotics to beneficially alter gut microflora and affect the metabolism of pathogenic microbes maintains gut health and enhances

\footnotetext{
* Corresponding Author: A. Q. Sazili. Tel: +60-3-89474870, Fax: +60-3-89381024, E-mail: awisqurni@gmail.com

${ }^{2}$ Department of Veterinary Preclinical Sciences, Faculty of Veterinary Medicine, Universiti Putra Malaysia, 43400 UPM Serdang, Selangor D.E., Malaysia.

3 Institute of Tropical Agriculture, Universiti Putra Malaysia, 43400 UPM Serdang, Selangor D.E., Malaysia.

${ }^{4}$ Halal Products Research Institute, Universiti Putra Malaysia, 43400 UPM Serdang, Selangor D.E., Malaysia.

${ }^{5}$ Department of Animal Science, Faculty of Agriculture, Usmanu Danfodiyo University, P.M.B. 2346, Sokoto, Nigeria.

Submitted Aug. 21, 2013; Accepted Nov. 7, 2013; Revised Nov. 27, 2013
}

the production performance of livestock (Biedrzycka, 2003). Antibiotic growth promoters enable the growing animals to efficiently digest their feed, derive maximum benefits from feed (NOAH, 2001). Despite the numerous benefits derived from the use of antibiotics, there are also health concerns on its usage such as the resistance issue in human pathogens (Chiquette, 2009). Antibiotics have residual effects in tissues and organs long after withdrawal in animals thus causing genotoxicity and resistance in microbes infecting consumers (Rolfe, 2000). The hazardous effects of antibiotics justify the ban on its usage in animal feed by the European Union in 2006 (Chiquette, 2009). Nonetheless, the prohibition of antibiotics in animal feed unavoidably overrides the numerous benefits derived from it. Thus, there is a need to find alternatives to antibiotics in order to bridge the existing gap between improved animal performance and safety of animal products to consumers.

Hence, the search for natural growth promoters that can stabilize digestibility, improve feed efficiency and growth performance and lower mortality rate in animals (Frankic et 
al., 2009) and consequently lead to higher profitability in livestock production. Goats are prominent browsers that generally browse on about 104 species of plants, out of which, 60\% are herbs (Hussain and Durrani, 2009). Herbs have been identified as the primary sources of natural polyphenols (Okuda, 2005) exhibiting antimicrobial activities (Sivakumaran et al., 2004; Durmic et al., 2008; Parvataneni and Koduru, 2010; Sule et al., 2010). Herbs contain a wide range of bioactive compounds, which affect the digestion process in many ways. Most herbs stimulate the secretion of saliva while others enhance the biosynthesis of bile acids in the liver and their excretion in bile (Srinivasan, 2005). Besides their effects on bile synthesis and enzyme activity, extracts from herbs and spices also accelerate the digestion and shorten the time of feed passage through the digestive tract (Platel and Srinivasan, 2001; Suresh and Srinivasan, 2007). Herbs in the diets of animals could have significant impact on feed intake, meat quality and composition (Priolo et al., 2000; 2002; Karami et al., 2010). However, the presence of high levels of herbs in feed have been reported to be responsible for decreased feed intake (Onanong et al., 2009; Karami et al., 2010), growth rate, feeding efficiency (Karami et al., 2010) and live-weight gain (Priolo et al., 2000). The influence of herbal supplementation in ruminants particularly goats has not been fully explored. Andrographis paniculata which is also known as king of bitter or biles of earth has been reported to exhibit antimicrobial properties (Parvataneni and Koduru, 2010; Sule et al., 2010). Okuda (2005) reported that there are differences in the polyphenolic composition in various parts of herb.

Due to the aforementioned attributes of AP, it is possible that different parts of AP will beneficially alter gut microflora, improve feed intake and efficiency and enhance performance characteristics in goats. The objective of this study was to evaluate the effects of Andrographis paniculata on growth performance and carcass characteristics in goats.

\section{MATERIALS AND METHODS}

\section{Propagation and processing of Andrographis paniculata}

Andrographis paniculata (AP), was propagated and harvested after three months from an irrigated plot in the research farm of the Department of Animal Science, Universiti Putra Malaysia. The herb was oven-dried to a moisture content of $10 \%$, ground and sieved through a 3 $\mathrm{mm}$ sieve, packed in air-tight polyethylene bags and stored in a cool, dry place as recommended by Hagerman (1988).

\section{Experimental diet and management of animals}

The feeding trial was conducted at Ar-Raudhah Biotech Farm Pty. Ltd. located in Kuang, Selangor, Malaysia.
Twenty-four, 4 months old Boer bucks were used in this study. The animals were randomly allotted to 3 different dietary groups: i) AP0 (Basal diet, $\mathrm{n}=8$ ); ii) APL (Basal diet $+1.5 \%$ dried leaf powder of Andrographis paniculata, $\mathrm{n}$ $=8$ ) and iii) APWP (Basal diet $+1.5 \%$ dried whole plant of Andrographis paniculata, $\mathrm{n}=8$ ). The diets were formulated in accordance with NRC (2007). The composition of ingredients and nutrients of the diets are as presented in Table 1. The diets were offered ad libitum as two separate meals at regular intervals between 7:00 am and 6:30 pm. At 7:30 am, the herb was mixed with the concentrate and fed to the animals, and at 12:00 pm, roughages were provided in the form of oil palm frond, rice husk and grasses. The same procedure was repeated between 4:00 pm and 6:30 pm, daily. The feed was offered daily at $3 \%$ of bodyweight DM intake throughout the experimental period. The animals were allowed ad libitum access to clean and cool drinking water. The left over feed was removed and weighed daily to determine voluntary DM intake. The initial average body weight of each group was recorded as $20.14 \pm 1.03 \mathrm{~kg}$ (AP0), $20.13 \pm 0.13 \mathrm{~kg}$ (APL) and 20.29 $\pm 0.18 \mathrm{~kg}$ (APWP). The animals were then group penned (wooden, slatted floor of $0.8 \mathrm{~m}$ above the ground). Each pen was provided with watering and feeding facilities. The feeding trial was conducted following the guidelines of the research policy of the Universiti Putra Malaysia on animal ethics. The entire

Table 1. Feed composition and nutrient content of the experimental diets

\begin{tabular}{lrcc}
\hline \multirow{2}{*}{ Ingredients } & \multicolumn{3}{c}{ Diets } \\
\cline { 2 - 4 } & AP0 & APL & APWP \\
\hline Oil palm frond (\%) & 40.00 & 40.00 & 40.00 \\
Rice husk (\%) & 10.00 & 10.00 & 10.00 \\
Fresh grasses (\%) & 10.00 & 10.00 & 10.00 \\
Zeolite (\%) & 0.05 & 0.05 & 0.05 \\
Concentrate (Goat pellet, \%) & 40.00 & 40.00 & 40.00 \\
AP0 (\%) & 0 & 0 & 0 \\
APL (\%) & 0 & 1.5 & 0 \\
APWP (\%) & 0 & 0 & 1.5 \\
Nutrients content & & & \\
Gross energy (MJ/kg) & 4.96 & 4.98 & 4.98 \\
Crude protein (\%) & 16.79 & 16.79 & 16.79 \\
Crude fibre (\%) & 25.12 & 25.14 & 25.14 \\
Ether extract (\%) & 5.89 & 5.80 & 5.80 \\
Calcium (\%) & 1.41 & 1.41 & 1.41 \\
Phosphorus (\%) & 1.03 & 1.03 & 1.03 \\
Acid detergent fibre (\%) & 30.10 & 30.94 & 30.98 \\
Neutral detergent fibre (\%) & 48.58 & 48.64 & 48.56 \\
Ash (\%) & 5.04 & 5.15 & 5.16 \\
Dry matter (\%) & 89.86 & 89.88 & 89.89 \\
\hline APL Bas
\end{tabular}

$\mathrm{APL}=$ Basal diet with $1.5 \%$ Andrographis paniculata leaves. APWP $=$ Basal diet with $1.5 \%$ Andrographis paniculata whole plant. AP0 or Control = Basal diet without Andrographis paniculata . 
feeding trial lasted for 100 consecutive days.

\section{Feed intake and growth performance}

During the trial, feed intake was recorded daily, while growth performance was monitored by weighing the animals at the beginning of the experiment and subsequently on a monthly basis. The average daily gains of the animals were estimated in order to determine feed efficiency. The efficiency of feed utilization and live weight gains were monitored monthly and calculated as follows:

Efficiency of feed utilization $=$ Feed intake/weight gain

Live weight gain $=$ New live weight-initial live weight

\section{Slaughtering procedure and carcass measurements}

At the end of the experiment, the animals were subjected to overnight fasting, recorded for their empty live weight and humanely slaughtered by the severance of carotid arteries and jugular veins. Slaughtering was carried out in a research abattoir at the Department of Animal Science, Universiti Putra Malaysia. The entire handling and slaughtering procedures were conducted according to the Malaysian Standards 1500: 2009 (Department of Standards Malaysia, 2009). After slaughter, the heads were removed at the atlanto-occipital joint, while the fore and hind legs were removed at the carpal and tarsal joints, respectively. The animals were skinned while suspended by their achilles tendon. Carcass and non-carcass components were weighed immediately after slaughter. The heart, liver, spleen, kidney and lungs were weighed together and designated as pluck. The non-carcass components such as head, skin and feet were also weighed and designated as offal. The weight of digestive contents (gut fills) was computed as the difference between full and empty digestive tract (rumen and intestines). Prior to skinning and the removal of the visceral organs from the carcass, the oesophagus was tied with nylon string to prevent contamination of carcass by the gut contents. Visceral fats were removed and weighed. The carcasses were weighed immediately after dressing which was designated as hot carcass weight. The whole carcasses were then chilled at $4^{\circ} \mathrm{C}$ for $24 \mathrm{~h}$ after which, the carcasses were re-weighed and recorded for cold carcass weight. Each carcass was split longitudinally to left and right halves. Each half was further split into fore and hind quarters using a carcass splitting saw (Model No.3334, The biro MFG. Co. Marblehead, Ohio). The rib eye area $\left(\mathrm{cm}^{2}\right)$ was measured between the 12th and 13th rib (Bock et al., 1991) using tracing paper by two-dimension polygons area calculator software (Branscome and Jesseman, 1999). The left half was dissected into components of lean, bone, fat and for the subsequent determination of lean to bone and lean to fat ratios. The physical composition of lean, fat and bone of the overnight chilled left half carcass was carried out by manual dissection and tissue weighing before calculated and finally expressed as percentages of each tissue per whole carcass weight. The amount of non-carcass components such as offal (head, legs and skin) was determined as a percentage of slaughter weight. The gut fill was recorded as percentages of total weight of gut (rumen and intestine including their contents) and the viscera (rumen and intestines) were reported as percentages of total weight of gut (including their contents) while the pluck (heart, liver, kidney and lungs) were weighed and recorded as percentages of carcass weight. The compositions of visceral fat, subcutaneous fat, inter-muscular fat as well as fat in pluck (heart, liver, kidney, and lungs) were recorded as percentages of total trimmable fats.

\section{Statistical analysis}

The experiment followed a completely randomized design (CRD). Data were analyzed using the GLM procedures of SAS Version 9.2 software (Statistical Analysis System, SAS Institute Inc, Cary, NC, USA). Significance was set at $\mathrm{p}<0.05$ and means were separated by Duncan multiple range test.

\section{RESULTS AND DISCUSSION}

\section{Growth performance}

There were no differences $(p>0.05)$ in initial live weight among the dietary treatment groups. This indicated homogeneity in the weight of animals used in the study. At the end of the feeding trial, goats fed APWP diet had higher weight $(p<0.05)$ compared with those fed AP0 diet. However, the final weight of goats fed on APL was comparable to those assigned on diets APWP and AP0. Slaughter live weight, weight gain $(\mathrm{kg})$, average daily weight gain $(\mathrm{g} / \mathrm{d})$ and feed to gain ratio followed the same trend as the final weight gain (Table 2). Feed to gain ratio was better $(\mathrm{p}<0.05)$ in goats fed APWP diet compared with those subjected to AP0 diet. The values observed in goats fed APL diet were not different $(\mathrm{p}>0.05)$ from APWP and AP0 (Table 2). Generally, goats fed APWP and APL diets performed $(\mathrm{p}<0.05)$ better in terms of the aforementioned parameters. Goats fed APWP diet consumed more feed $(p<0.05)$ and this can be translated as better performance. A key factor in efficient weight gain is optimum nutrient intake (Rose and Howlider, 1987). The better performance observed in goats fed APWP diet could be due to increased energy intake (Mahgoub et al., 2000; Haddad, 2005). It is also possible that the $16.79 \%$ crude protein and $4.98 \mathrm{MJ} / \mathrm{kg}$ of gross energy used in this study were adequate to support live weight and gains in all the treatments. The average daily gain of 103.18 to $171.43 \mathrm{~g} / \mathrm{d}$ observed in this study 
Table 2. Growth performance of goats fed diets containing Andrographis paniculata

\begin{tabular}{lccc}
\hline \multirow{2}{*}{ Parameters } & \multicolumn{3}{c}{ Dietary treatments } \\
\cline { 2 - 4 } & AP0 $(\mathrm{n}=7)$ & APL $(\mathrm{n}=8)$ & APWP $(\mathrm{n}=7)$ \\
\hline Initial weight $(\mathrm{kg})$ & $20.14 \pm 1.03$ & $20.13 \pm 0.13$ & $20.29 \pm 0.18$ \\
Final weight $(\mathrm{kg})$ & $29.43 \pm 2.44^{\mathrm{b}}$ & $31.75 \pm 0.82^{\mathrm{ab}}$ & $35.57 \pm 1.17^{\mathrm{a}}$ \\
Slaughter live weight $(\mathrm{kg})$ & $25.66 \pm 2.06^{\mathrm{b}}$ & $27.98 \pm 1.04^{\mathrm{ab}}$ & $31.83 \pm 1.21^{\mathrm{a}}$ \\
Weight gain (kg) & $9.29 \pm 2.14^{\mathrm{b}}$ & $11.63 \pm 0.87^{\mathrm{ab}}$ & $15.43 \pm 1.19^{\mathrm{a}}$ \\
Average daily feed intake (g/d) & $882.86 \pm 73.15^{\mathrm{b}}$ & $952.50 \pm 24.55^{\mathrm{ab}}$ & $1,067.14 \pm 35.17^{\mathrm{a}}$ \\
Total feed intake (kg) & $79.46 \pm 6.58^{\mathrm{b}}$ & $85.73 \pm 2.21^{\mathrm{ab}}$ & $96.04 \pm 3.17^{\mathrm{a}}$ \\
Average daily weight gain (g/d) & $103.18 \pm 23.72^{\mathrm{b}}$ & $129.17 \pm 9.6^{\mathrm{ab}}$ & $171.43 \pm 13.25^{\mathrm{a}}$ \\
Feed to gain ratio & $11.76 \pm 2.93^{\mathrm{a}}$ & $7.56 \pm 0.37^{\mathrm{ab}}$ & $6.35 \pm 0.27^{\mathrm{b}}$ \\
\hline
\end{tabular}

$\overline{\mathrm{a}, \mathrm{b}, \mathrm{c}}$ Means within a row with different superscripts differ significantly at $\mathrm{p}<0.05$.

$\mathrm{APL}=$ Basal diet with 1.5\% Andrographis paniculata leaves. APWP = Basal diet with 1.5\% Andrographis paniculata whole plant. $\mathrm{AP} 0$ or Control $=$ Basal diet without Andrographis paniculata .

was higher than that reported by Johnson et al. (2010) whose findings indicated average daily gain of $49.61 \mathrm{~g}$ and $81.86 \mathrm{~g}$ in goats fed forages and grains, respectively. The higher final body weight $(35.57 \pm 1.17 \mathrm{~kg})$ exhibited by goats fed APWP was within the range of 34.98 to $39.15 \mathrm{~kg}$ as reported by Johnson et al. (2010). In all treatment groups, the average final live weight recorded in this study was within the range of 25.40 to $49.50 \mathrm{~kg}$ as reported earlier in Boer goats fed grasses and alfalfa based diet (Wildeus et al., 2007). Perhaps it is clear that many of the desirable effects of antibiotics used as growth stimulants act through modification of the rumen microbial population responsible for breakdown of nutrients (Simone et al., 2008). Andrographis paniculata could have probably exhibited a similar mode of action by altering the rumen fermentation processes and maintaining a efficient digestive function as reported by Gupta et al. (1990). Bioactive compounds in herbs vary in their mode of action on digestive processes. Most bioactive compounds in herbs enhance the synthesis of bile acids in the liver and their excretion in bile (Srinivasan, 2005). Bile is crucial for digestion and absorption of fats and fat-soluble vitamins in the small intestine.

There was no difference $(\mathrm{p}>0.05)$ in weight gain between goats fed the control (AP0) and APL diets. This could be due to the presence of some bioactive compounds such as polyphenol in the control diet. Earlier, Frutos et al. (2004) and Nackz et al. (2001) reported that polyphenols including tannins are found in varying levels within the plant kingdom. They are low in grasses and high in herbaceous legumes, trees and shrubs that are used as sources of feed for livestock in the tropics. Since there is variation in polyphenols among different parts of AP plant (Okuda, 2005; Yusuf et al., 2012), it is possible that the most active compounds are present in adequate amount in the stem and root of AP. This could possibly explain the significantly higher weight gain observed in goats fed
APWP diet. The polyphenols in AP act as enzymes inducer by binding to the enzymes, activating them for several metabolic processes in the body particularly digestion and absorption of nutrients (Thiyagarajan et al., 2011).

\section{Feed intake}

Higher feed intake $(p<0.05)$ was observed in goats fed diet containing APWP than those in the AP0 group, while the feed intake recorded in goats fed APL was comparable to those observed in goats fed AP0 and APWP (Table 2). The high feed intake observed in this study contradicts the earlier findings reported by Karami et al. (2010). In their study, lower feed intake was observed in Kacang goats supplemented with $0.75 \%$ Andrographis paniculata compared to control. The higher feed intake observed in this study could be due to the inclusion of toxic binder in the form of zeolite in the feed (Table 1). This toxic binder may have improved the physical properties of the feed by increasing flow ability, reducing moisture levels, or act as anti-caking agent thereby making the feed to retain its palatability. Bengaly and Nsahlai (2007) also observed increased feed intake with dietary supplementation of wattle tannin to goats. Boer goats can perform better than sheep on a diet low in metabolizable energy (Sheridan et al., 2003). The ability of goats to tolerate toxins (Papachristou et al., 2005) allows them to feed on a diet high in polyphenols without reducing their performance as long as the nutrient requirements are met. This is because detoxification process requires major dietary components like energy and protein (Baraza et al., 2009). Thus, the $16.79 \%$ protein and 4.98 $\mathrm{MJ} / \mathrm{kg}$ of gross energy used in this study, was adequate to support the performance of the goats. Goats browse on about 104 species of shrubs out of which $60 \%$ are herbs of different nature (Hussain and Durrani, 2009).

It was possible that concentrations of polyphenols including tannins in AP of up to 3\% as observed by Yusuf et al. (2012) would reduce feed palatability and feed intake as 
Table 3. Carcass characteristics of goats fed diets containing Andrographis paniculata

\begin{tabular}{|c|c|c|c|}
\hline \multirow{2}{*}{ Parameters } & \multicolumn{3}{|c|}{ Dietary treatments } \\
\hline & AP0 $(n=7)$ & $\operatorname{APL}(\mathrm{n}=8)$ & $\operatorname{APWP}(n=7)$ \\
\hline Hot carcass weight $(\mathrm{kg})$ & $11.86 \pm 0.10^{\mathrm{c}}$ & $15.16 \pm 0.39^{b}$ & $17.54 \pm 0.25^{\mathrm{a}}$ \\
\hline Cold carcass weight $(\mathrm{kg})$ & $11.41 \pm 0.10^{\mathrm{c}}$ & $14.77 \pm 0.38^{\mathrm{b}}$ & $16.99 \pm 0.20^{\mathrm{a}}$ \\
\hline Chilling loss (\%) & $0.45 \pm 0.07^{\mathrm{b}}$ & $0.39 \pm 0.04^{\mathrm{c}}$ & $0.54 \pm 0.18^{\mathrm{a}}$ \\
\hline Dressing percentage $(\%)$ & $40.26 \pm 4.77^{b}$ & $46.64 \pm 1.30^{\mathrm{a}}$ & $48.14 \pm 1.89^{\mathrm{a}}$ \\
\hline Rib eye area $\left(\mathrm{cm}^{2}\right)$ & $4.79 \pm 0.10^{\mathrm{bc}}$ & $6.17 \pm 0.62^{\mathrm{b}}$ & $9.08 \pm 0.64^{\mathrm{a}}$ \\
\hline Back fat thickness (mm) & $2.32 \pm 0.12^{\mathrm{a}}$ & $1.56 \pm 0.08^{\mathrm{b}}$ & $1.18 \pm 0.20^{\mathrm{c}}$ \\
\hline Carcass:fat & $4.74 \pm 0.36^{\mathrm{b}}$ & $9.50 \pm 1.01^{\mathrm{a}}$ & $10.66 \pm 0.53^{\mathrm{a}}$ \\
\hline Lean:bone & $6.19 \pm 0.69^{\mathrm{b}}$ & $9.93 \pm 0.32^{\mathrm{a}}$ & $9.68 \pm 0.67^{\mathrm{a}}$ \\
\hline Lean:fat & $3.82 \pm 0.31^{\mathrm{c}}$ & $10.46 \pm 0.95^{\mathrm{ab}}$ & $12.85 \pm 0.94^{\mathrm{a}}$ \\
\hline Lean $(\%)$ & $69.32 \pm 2.05^{\mathrm{b}}$ & $83.15 \pm 0.68^{\mathrm{a}}$ & $84.15 \pm 0.46^{\mathrm{a}}$ \\
\hline Fat $(\%)$ & $21.76 \pm 1.48^{\mathrm{a}}$ & $11.24 \pm 0.98^{\mathrm{b}}$ & $9.52 \pm 0.46^{\mathrm{b}}$ \\
\hline Bone $(\%)$ & $11.98 \pm 1.19^{\mathrm{a}}$ & $8.43 \pm 0.24^{\mathrm{b}}$ & $8.89 \pm 0.48^{\mathrm{b}}$ \\
\hline
\end{tabular}

a,b,c Means within a row with different superscripts differ significantly at $\mathrm{p}<0.05$.

$\mathrm{APL}=$ Basal diet with 1.5\% Andrographis paniculata leaves. APWP = Basal diet with $1.5 \%$ Andrographis paniculata whole plant.

AP0 or Control $=$ Basal diet without Andrographis paniculata .

documented earlier by Karami et al. (2010). However, Bengaly et al. (2007) did not observe any changes in feed intake of goats fed diets containing up to $3 \%$ tannin. Provenza (1995) postulated that more than 3\% level of condensed tannin in the diet could be detrimental to the animals' appetite. Herbs contain a wide variety of active compounds that tends to stimulate the secretion of saliva (Srinivasan, 2005) and appetite. This could be the reason why goats on treatments AP (APL and APWP) consumed significantly more feed per unit metabolic body weight and utilised it more efficiently than their counterparts on treatment AP0. This accounted for their superiority in growth rate.

\section{Carcass characteristics}

The weights of hot and cold carcasses differed $(p<0.05)$ among the dietary treatments (Table 3 ). The highest hot and cold carcass weights were presented by goats fed APWP diet, followed by APL and AP0. The higher feed intake, weight gain and better weight to gain ratio are parallel with the heavier weights of hot and cold carcasses observed in goats fed APWP. Shrinkage during $24 \mathrm{~h}$ chilling in the carcasses of goats fed APWP diet was higher $(p>0.05)$ than the other treatments. Shrinkage was significantly lower in the carcasses of goats fed APL diet than fed AP0 diet (Table 3). Lower shrinkage in the carcasses of goats fed APL diet contradicts the report of Beshir and Babiker (2009) that carcasses high in subcutaneous fat cover suffer less moisture loss during $24 \mathrm{~h}$ chilling. In this study, the group of goats with higher fat cover (Table 4) tended to have higher moisture loss than those with less fat cover.

Dressing percentage is both a yield and valuedetermining factor and is therefore an important yardstick in assessing performance of meat producing animals. Significantly higher dressing percentage was observed in goats fed APWP and APL diet compared with goats fed AP0 diet (Table 3). The values observed in goats fed AP treatments (APL and APWP) were within the expected

Table 4. Composition of non-carcass components of goats fed diets containing Andrographis paniculata

\begin{tabular}{lccc}
\hline \multirow{2}{*}{ Parameters } & \multicolumn{3}{c}{ Treatments } \\
\cline { 2 - 4 } & AP0 $(\mathrm{n}=7)$ & APL $(\mathrm{n}=8)$ & APWP $(\mathrm{n}=7)$ \\
\hline Offal-head, legs and skin (\% of slaughter weight) & $22.56 \pm 0.65$ & $21.91 \pm 0.50$ & $23.09 \pm 0.56$ \\
Gut fill (\% of total weight of rumen and intestine) & $52.78 \pm 5.52^{\mathrm{b}}$ & $70.46 \pm 3.88^{\mathrm{a}}$ & $79.67 \pm 1.75^{\mathrm{a}}$ \\
Viscera - rumen and intestines (\% of total weight including contents ) & $47.22 \pm 5.52^{\mathrm{a}}$ & $29.54 \pm 3.88^{\mathrm{b}}$ & $20.33 \pm 1.76^{\mathrm{b}}$ \\
Pluck-heart, liver, kidney and lungs (\% of carcass weight) & $4.99 \pm 0.31$ & $4.66 \pm 0.35$ & $5.05 \pm 0.40$ \\
Viscera fat (\% of total trimmable fat) & $13.59 \pm 3.28^{\mathrm{b}}$ & $24.35 \pm 4.11^{\mathrm{a}}$ & $28.97 \pm 3.39^{\mathrm{a}}$ \\
Subcutaneous fat (\% of total trimmable fat) & $40.00 \pm 0.01^{\mathrm{a}}$ & $35.22 \pm 0.44^{\mathrm{b}}$ & $33.95 \pm 2.55^{\mathrm{b}}$ \\
Inter-muscular fat (\% of total trimmable fat) & $35.00 \pm 0.01$ & $35.63 \pm 0.63$ & $35.00 \pm 0.01$ \\
Fat in pluck -heart, liver, kidney and lungs (\% of total trimmable fat) & $11.40 \pm 3.28^{\mathrm{a}}$ & $4.81 \pm 2.69^{\mathrm{ab}}$ & $2.07 \pm 1.21^{\mathrm{b}}$ \\
\hline
\end{tabular}

$\overline{a, b, c}$ Means within a row with different superscripts differ significantly at $\mathrm{p}<0.05$.

$\mathrm{APL}=$ Basal diet with $1.5 \%$ Andrographis paniculata leaves. APWP = Basal diet with $1.5 \%$ Andrographis paniculata whole plant.

AP0 or Control = Basal diet without Andrographis paniculata . 
range of $43.9 \%$ to $55.7 \%$ as reported for Boer goats, South Africa indigenous, Angora and Kacang crossbred goats (Ebrahimi et al., 2008; Johnson et al., 2010). Mioč et al. (2007) documented $43.85 \%$ dressing percentage for lambs fed olive cake. The dressing percentage observed in goats fed on $1.5 \%$ APL was however, comparable to $46.70 \%$ as observed by Karami et al. (2010) and $46.33 \%$ as reported earlier by Ebrahimi et al. (2008) for Kacang goats fed $0.50 \%$ Andrographis paniculata leaf powder and $50 \%$ oil palm frond pellet, respectively. Dressing percentage of $48.71 \%$ observed by Ebrahimi et al. (2008) when Kacang goats were fed $25 \%$ oil palm frond pellet was similar to that which was reported for goats fed APWP in the present study. Wildeus et al. (2007) reported higher carcass dressing percentage for Spanish and Boer goats fed grass and alfalfahay-based diets with limited concentrate supplementation.

In this study, rib eye muscle area was larger $(p<0.05)$ in goats fed APWP diet compared with AP0 and APL. It was also observed that the rib eye muscle area of goats fed AP0 and APL diets were not different (Table 3). The results obtained from the goats fed APWP diet indicate that dietary supplementation of APWP to goats significantly increased rib eye area, which is a good prediction tool for carcass muscle. The higher values observed in the goats fed APWP were similar to the $9.5 \pm 0.4$ and $9.9 \pm 0.4$ values reported for Spanish goats fed grass and alfalfa based diets, respectively. Generally, the values observed in the present study are lower than $14.3 \pm 0.7$ and 13.6 \pm 0.5 reported for Boer goats fed the same diets as the Spanish goats as reported by Wildeus et al. (2007). Differences in breed of goats used might not be the reason for the discrepancies between earlier studies and the present study. The type of diet fed (grass and alfalfa-hay-based diets with limited concentrate supplementation) and climatic factors (both earlier studies were conducted in Virginia State in the USA) the first trial (Spanish goats) was conducted in fall (late August through November) while the second trial (Boer goats) was conducted in December through March the following year) could also be contributing factors to variations in the results observed in the present study and study conducted by Wildeus et al. (2007). Apart from these, the goats used by Wildeus et al. (2007) were castrated at birth and castrated animals tend to have more gain than intact ones. Rib eye area as reported by Karami et al. (2010) in goats fed 0.25 and $0.75 \%$ Andrographis paniculata leaf powder were 11.3 and $12.4 \mathrm{~cm}^{2}$, which were higher than those observed in the present study.

Back fat thickness $(\mathrm{mm})$ was significantly different among the treatments with the back fat of goats fed AP0 diet found to be thicker $(\mathrm{p}<0.05)$ than those subjected to APL and APWP dietary treatments (Table 3). The thinner back fat values observed in the APL and APWP groups are comparable to $1.21 \mathrm{~mm}$ as observed by Karami et al. (2010).
Ebrahimi et al. (2008) observed a value of $2.00 \pm 0.26 \mathrm{~mm}$ back fat thickness in Kacang goats fed $50 \%$ oil palm frond pellets and this comparable to the value recorded in goats fed AP0 (control diet). The back fat thickness observed in Spanish and Boer goats fed grass as reported by (Wildeus et al., 2007) were similar to those observed in this study. However, in the same study conducted by Wildeus et al. (2007), Boer goats fed alfalfa indicated thicker back fat than the overall observed values in the present study. The result of this study corroborates the reports of Colomer-Rocher et al. (1992) and Kirton (1988) that goats usually tend to deposit more internal fat and less subcutaneous and intramuscular fat.

Significantly (higher carcass: fat, lean: bone and lean: fat as well as proportions of meat were observed in the carcasses of goats fed APWP and APL compared with AP0 (control diet). Higher lean and muscle proportion could be explained by more efficient digestion of nutrients while lower visible fats contents could probably be due to the effect of AP in altering the rumen fermentation processes and hence helping in maintaining an efficient digestive function as observed in the findings of Gupta et al. (1990). Gaili and Ali (1985) suggested that diet composition is more important for goats than sheep. Karami et al. (2010) reported $67.80 \%$ total meat and $20.00 \%$ for total bone obtained in local Kacang crossbred male goats fed diet containing dried AP leaf powder. Ebrahimi et al. (2008) reported lower $1.42,1.57$, and 1.11 muscle to bone and 4.78 , 4.35 , and 6.91 muscle to fat ratios of Kacang goats fed varying levels of oil palm frond pellets. These values however are lower than the values observed in the present study, probably due to the small body size of the local Kacang goats compared with the meat type Boer goats used in the present study.

There were significant differences in the proportions of viscera (rumen and intestines) among the treatments. The viscera of goats fed AP0 was higher $(\mathrm{p}<0.05)$ than those fed APWP and APL (Table 4). This is suggestive that in goats fed AP0 diet, most of the nutrients could have been directed to internal visceral development rather than building of muscles. Gut fill percentages were also different $(\mathrm{p}<0.05)$ among the treatment groups (Table 4). Similarly, higher gut fill percentages $(p<0.05)$ were observed in the rumen of goats fed APWP and APL diets. This suggests possible suppression in the activity of rumen micro-organisms which could have reduced the rate of digestion in the rumen of goats fed diets containing Andrographis paniculata (APL and APWP). In addition, higher gut fill due to high fibre content of oil palm frond and rice husk included in the diets (Table 1) had earlier been observed by Beshir and Babiker (2009). Apart from the effect of AP on bile synthesis and enzyme activity, extracts from herbs and spices have also accelerated digestion and shorten the time of feed passage 
through the digestive tract (Patel and Srinivasan, 2001; Suresh and Srinivasan, 2007).

The proportions $(\%)$ of viscera fat in goats fed APL and APWP diets were significantly higher than those fed the AP0. The proportions of subcutaneous fat were also different $(\mathrm{p}<0.05)$ among the treatments (Table 4). Goats fed APL and APWP diets had a lower proportion of subcutaneous fat compared with goats on the AP0. Karami et al. (2010) reported a lower proportion of subcutaneous fat, as $2.21 \%$ in goats fed dried AP leaf powder. However, this is lower than the values observed in the present study. Viscera adipocytes are metabolically active and more sensitive to lipolysis than the subcutaneous adipocytes. Viscera adipocytes has greater capacity to generate free fatty acids and to uptake glucose than subcutaneous adipocytes (Ibrahim, 2010). This could probably be the reason for better growth performance in AP supplemented goats. The proportions of inter-muscular fat were similar ( $>0.05)$ across the treatments. This is an indication that treatment had no effect on the proportion of inter-muscular fat. The proportions of inter-muscular fat observed in this study were higher than the values of $3.74 \%$ and $3.25 \%$ reported for $0.25 \%$ and $0.75 \%$ AP leaf powder were fed to Kacang goats (Karami et al., 2010). This could be due to differences in the breeds of animals used in both studies. Relatively, the proportions of pluck (heart, liver, kidney, and lungs) and offal (head, legs, and skin) were not affected by the treatment. This shows that nutrients derived from the feeds were solely directed to increasing carcass components rather than the non-carcass parts. Generally, the better performance observed with AP supplemented goats when compared with AP0 could be due to enzyme inducing action of bioactive compound in AP plant as reported by Thiyagarajan et al. (2011).

\section{CONCLUSION}

The results of this study indicate that the inclusion of Andrographis paniculata in the diet of goats has significantly improved their growth performance and meat yield. Therefore, Andrographis paniculata can potentially be used as a natural promoter in ruminants for better growth performance, carcass characteristics and meat production. Nevertheless, further studies should be carried out to characterize the bioactive compounds in Andrographis paniculata and their individual effects on performances in meat goats with special emphasis on rumen fermentation characteristics and nutrient utilization.

\section{ACKNOWLEDGEMENTS}

The authors gratefully acknowledge Universiti Putra Malaysia for the funding through Research University
Grant Scheme Initiative 2 (Project No.: 01-02-12-1675RU) and Research University Grant Scheme Initiative 6 (Project No.: 01-02-11-1340RU).

\section{REFERENCES}

Baraza, E., J. A. Ho`dar, and R. Zamora. 2009. Consequences of plant-chemical diversity for domestic goat food preference in Mediterranean forests. Acta Oecol. 35:117-127.

Bengaly, K., S. Mhlongo, and I. V. Nsahlai. 2007. The effect of wattle tannin on intake, digestibility, nitrogen retention and growth performance of goats in South Africa. Livest. Res. Rural Develop. 19:50.

Beshir, A. A. and S. A. Babiker. 2009. The effect of substitution of groundnut cake by water melon seed cake (Citrullus lanatus) in ration for lamb fattening in Sudan. Res. J. Agric. and Biol. Sci. 5:1130-1142.

Biedrzycka, E. 2003. Probiotics as alternative for antibiotics. J. Antimicrob. Chemother. 52: 489-492.

Bock, B. J., D. L. Harmon, R. T. Brandt, and J. E. Schneider. 1991. Fat source and calcium level effects on finishing steer performance, digestion and metabolism. J. Anim. Sci. 69:2211 $-2224$.

Branscome, J. and C. Jesseman. 1999. ArC software download and user guide page. http://www.concentric.net/ Jbrans/ArC/ download.htm.

Chiquette, J. 2009. The role of probiotics in promoting dairy production. WCDS Adv. Dairy Technol. 2:143-157.

Colomer-Rocher, F., A. H. Kirton, G. J. K. Merces, and D. M. Duganzich. 1992. Carcass composition of New Zealand Saanen goats slaughtered at different weights. Small Rumin. Res. 7:161-173.

Durmic, Z., C. S. McSweeny, G. W. Kemp, P. P. Hutton, R. J. Wallace, and P. E. Vercoe. 2008. Australian plants with potential to inhibit bacteria and processes involved in ruminal biohydrogenation of fatty acids. Anim. Feed Sci. Technol. 145: 271-284.

Ebrahimi, M., M. A. Rajion, Y. M. Goh, and A. Q. Sazili. 2008. Carcass quality of Malaysian Kacang crossbred goats fed diets supplemented with oil palm fronds. In: Proceedings of the 29th Malaysian Society for Animal Production (MSAP) Annual Conference, 25-27 May, 2008, Penang, Malaysia. pp. 116-118.

Frankic, T., M. Voljc, J. Salobir, and V. Rezar. 2009. Use of herbs and spices and their extracts in animal nutrition. Acta Argiculturae Slovenica 94:95-102.

Frutos, P., M. Raso, G. Hervás, A. R. Mantecón, V. Pérez, and F. J. Giráldez. 2004. Is there any detrimental effect when a chestnut hydrolyzable tannins extract is included in the diet of finishing lambs? Anim. Res. 56:127-136.

Gaili, E. S. and A. E. Ali. 1985. Meat from Sudan desert sheep and goats: 2. Composition of the muscular and fatty tissues. Meat Sci. 13:229-236.

Gupta, S., M. A. Choudhry, J. N. S. Yadava, V. Srivastava, and J. S. Tandon. 1990. Anti-diarrhoeal activity of diterpenes of Andrographis paniculata (Kalmegh) against Escherichia coli enterotoxin in in vivo models. Int. J. Crude Drug Res. 28:273283.

Haddad, P. 2005. Weight changes with atypical antipsychotics in 
the treatment of schizophrenia. J. Psychopharmacol. 19 (Suppl 6):16-27.

Hagerman, A. E. 1988. Extraction of tannins from fresh and preserved leaves. J. Chem. Ecol. 14:453-461.

Huang, X. D., J. B. Liang, H. Y. Tan, R. Yahya, B. Khamseekhiew, and Y. W. Ho. 2010. Molecular weight and protein binding affinity of Leucaena condensed tannins and their effects on in vitro fermentation parameters. Anim. Feed Sci. Technol. 159: 81-87.

Hussain, F. and M. J. Durrani. 2009. Seasonal availability, palatability and animal preferences of forage plants in Harboi arid range land, Kalat, Pakistan. Pak. J. Bot. 41:539-554.

Ibrahim, M. M. 2010. Subcutaneous and visceral adipose tissue: structural and functional differences. Obes. Rev. 11:11-18.

Johnson, C. R., S. P. Doyle, and R. S. Long. 2010. Effect of feeding system on meat goat growth performance and carcass traits. Sheep Goat Res. J. 25:78-82.

Karami, M., A. R. Alimon, Y. M. Goh, Q. S. Awis, and M. Ivan. 2010. Effects of dietary herbal antioxidants supplemented on feedlot growth performance and carcass composition of male goats. Am. J. Anim. Vet. Sci. 5:33-39.

Kirton, A. H. 1988. Characteristics of goat meat including carcass quality and methods of slaughter, goat meat production in Asia. In: Proceedings of a workshop held in Tando Jam, Pakistan. pp. 273.

Mahgoub, O., C. D. Lu, and R. J. Early. 2000. Effects of dietary energy density on feed intake, body weight gain and carcass chemical composition of Omani growing lambs. Small Rumin. Res. 37:35-42.

Miočet, B., V. Pavić, I. Vnučec, Z. Prpić, A. Kostelić, and V. Sušić. 2007. Effect of olive cake on daily gain, carcass characteristics and chemical composition of lamb meat. Czech J. Anim. Sci. 52:31-36.

Naczk, M., R. Amarowicz, P. Zadernowski, and F. Shahidi. 2001. Protein precipitating capacity of condensed tannins of beach pea, canola hulls, evening primrose and faba bean. Food Chemist. 73:467-471.

NOAH. 2001. National office of animal health. Antibiotics for animals. http://www.noah.co.uk/issues/antibiotics.htm Last accessed 4 March, 2013.

NRC. 2007. National research council, nutrient requirements of small ruminant. Sixth edition, National Academy Press, Washington, DC, USA. pp. 384.

Okuda, T. 2005. Systematics and health effects of chemically distinct tannins in medicinal plants. Phytochemistry 66:20122031.

Onanong, P., W. Metha, W. Chalong, W. Sadudee, and C. Anusorn. 2009. Manipulation of ruminal fermentation and methane production by dietary saponins and tannins from mangosteen peel and soapberry fruit. Arch. Anim. Nutr. 63:389-400.

Papachristou, T. G., L. E. Dziba, and F. D. Provenza. 2005. Foraging ecology of goats and sheep on wooded rangelands. Small Rumin. Res. 59:141-156.

Parvataneni, R. and R. L. Koduru. 2010. Antimicrobial activity of the chloroform extracts of the root and the stem of Andrographis paniculata nees. Int. Res. J. Microbiol. 1:37-39.

Platel, K. and K. Srinivasan. 2001. Studies on the influence of dietary spices on food transit time in experimental rats. Nutr. Res. 21:1309-1314.
Priolo, A., D. Micol, J. Agabriel, S. Prache, and E. Dransfield, 2002. Effect of grass or concentrate feeding systems on lamb carcass and meat quality. Meat Sci. 62:179-185.

Priolo, A., G. C. Waghorn, M. Lanza, L. Biondi, and P. Pennisi. 2000. Polyethylene glycol as a means for reducing the impact of condensed tannins in carob pulp: Effects on lamb growth performance and carcass and meat quality. J. Anim. Sci. 78: 810-816.

Provenza, F. D. 1995. Post-ingestive feedback as an elementary determinant of food selection and intake in ruminants. J. Range Manage. 48:2-17.

Rolfe, R. D. 2000. The role of prebiotic cultures in the control of gastrointestinal health. J. Nutr. 130:396-402.

Rose, S. P. and M. A. R. Howlider. 1987. Temperature and the growth of broilers. World's Poult. Sci. J. 43:228-230.

Sheridan, R., L. C. Hoffman, and A. V. Ferreira. 2003. Production efficiency of South African Mutton Merino lambs and Boer goat kids receiving either a low or high energy feedlot diet. Small Rumin. Res. 50:75-82.

Simone, R., J. P. Anthony, and R. D. Frank. 2008. Plant bioactives for ruminant health and productivity. Review. Phytochemistry 69:299-322.

Sivakumaran, S., A. L. Molan, L. P. Meagher, B. Kolb, L. Y. Foo, G. A. Lane, G. A. Attwood, K. Fraser, and M. Tavendale. 2004. Variation in antimicrobial action of pro-anthocyanidins from Dorycnium rectum against rumen bacteria. Phytochemistry 65: 2485-2497.

Srinivasan, K. 2005. Spices as influencers of body metabolism: An overview of three decades of research. Food Res. Int. 38:77-86

Sule, A., Q. U. Ahmed, O. A. Samah, and M. N. Oma. 2010. Screening for anti-bacterial activity of Andrographis paniculata used in Malaysian folkloric medicine: a possible alternative for the treatment of skin infections. Ethnobotanical Leaflets 14:445-56.

Suresh, D. and K. Srinivasan. 2007. Studies on the in vitro absorption of spice principles - curcumin, capsaicin and piperine in rat intestines. Food Chem. Toxicol. 45:1437-1442.

Chandrasekaran, C. V., P. Thiyagarajan, H. B. Deepak, and A. Agarwal. 2011. In vitro modulation of LPS/calcimycin induced inflammatory and allergic mediators by pure compounds of Andrographis paniculata (King of bitters) extract. Int. Immunopharmacol. 11:79-84.

Widdowson, E. M. and D. Lister. 1991. Nutritional control of growth. In: Growth Regulation in Farm Animals (Ed. A. M. Pearson and T. R. Dutson). Adv. Meat Re. Elsevier, London, pp. 67-94.

Wildeus, S., J. M. Luginbuhl, K. E. Turner, Y. L. Nutall, and J. R. Collins. 2007. Growth and carcass characteristics in goat kids fed grass- and alfalfa-hay-based diets with limited concentrate supplementation. Publications from USDA-ARS/UNL Faculty. Paper 437. http://digitalcommons.unl.edu/usdaarsfacpub/437

Yusuf, A. L., A. Q. Sazili, M. Ebrahimi, Y. M. Goh, A. A. Samsudin, A. B. Idris, and A. R. Alimon. 2012. In vitro digestibility of diets containing different parts of Andrographis paniculata using rumen fluid from goats. J. Anim. Vet. Adv. 11:3921-3927. 